Arq. Bras. Med. Vet. Zootec., v.73, n.5, p.1171-1179, 2021

\title{
Evaluation of corn hybrids for silage grown in different locations
}

\author{
[Avaliação de híbridos de milho para silagem cultivados em diferentes locais] \\ M. Neumann ${ }^{(D)}$, E.H. Horst* ${ }^{*}$, F.B. Cristo ${ }^{(\mathbb{D})}$, A.M. Souza ${ }^{(\mathbb{D})}$, \\ D.C. Plodoviski ${ }^{(\mathbb{D})}$, L. Costa ${ }^{(\mathbb{D}}$
}

Universidade Estadual do Centro-Oeste, Unicentro, Guarapuava, PR, Brasil

\begin{abstract}
The aim of this study was to evaluate the yield, morphometric and chemical characteristics, and the digestibility of various corn hybrids cultivated in different locations for silage production. Four corn hybrids were grown: $\mathrm{P} 2866 \mathrm{H}, \mathrm{P} 3456 \mathrm{H}, \mathrm{P} 30 \mathrm{R} 50 \mathrm{VYH}$ and $\mathrm{P} 4285 \mathrm{YHR}$, in four locations, defined as farm A; B; C and D. The hybrid P4285YHR presented the highest plant and ear insertion heights $(2.72 \mathrm{~m}, 1.52 \mathrm{~m}$ respectively), with a minimum registered height of $2.63 \mathrm{~m}$ and $1.42 \mathrm{~m}$, for plant and ear insertion height, and for that reason it presented the highest yield of fresh biomass $\left(78,089 \mathrm{~kg} \mathrm{ha}^{-1}\right)$. The TND values showed trend very close to that observed in the DISMS of the whole-plant, with hybrid $\mathrm{P} 3456 \mathrm{H}$ presenting the highest estimated value (68.74\%), and the hybrid P4285YHR the lowest among them (65.25\%). In general, lower fibrous carbohydrates and lignin content, higher fibrous carbohydrates content, together with satisfactory grains participation in the plant structure led to a greater dry matter digestibility. Hybrids with lower plant heights do not necessarily have lower dry biomass yields, but hybrids of greater height and with high stem and leaf participation tend to have a higher aFDN content and less dry matter digestibility.
\end{abstract}

Keywords: growth altitude, fibrous carbohydrates, dry matter digestibility (DMS), vegetative fraction, varieties

\section{RESUMO}

O objetivo deste estudo foi avaliar o desempenho produtivo e as características morfométricas e químicas, além da digestibilidade de diferentes híbridos de milho cultivados em diferentes locais para produção de silagem. Foram cultivados quatro híbridos de milho: P2866H, P3456H, P30R50VYH e P4285YHR, em quatro locais, definidos como propriedades A; B; C e D. O híbrido P4285YHR apresentou as maiores alturas de planta e de inserção de espiga $(2,72 \mathrm{~m}, 1,52 \mathrm{~m}$, respectivamente), com altura mínima registrada, nos diferentes locais, de 2,63m e 1,42m, para altura de planta e inserção de espiga, e, por isso, apresentou o maior rendimento de biomassa fresca $\left(78.089 \mathrm{~kg} \mathrm{ha}^{-1}\right)$. Os valores calculados de NDT mostraram tendência muito próxima àquela observada na DISMS da planta inteira, tendo o híbrido P3456H apresentado o maior valor estimado (68,74\%), e o híbrido P4285YHR o menor entre eles (65,25\%). Em geral, menores concentrações de carboidratos fibrosos e lignina, maior teor de carboidratos fibrosos, juntamente com satisfatória participação de grãos na estrutura da planta, conduzem a uma maior digestibilidade da matéria seca. Híbridos com menores alturas de planta não necessariamente apresentam menores rendimentos de biomassa seca, mas híbridos de maior altura e com alta participação de colmo e folhas tendem a apresentar maior teor de aFDN e menor digestibilidade da matéria seca.

Palavras-chave: altitude de plantio, carboidratos fibrosos, digestibilidade da matéria seca (DMS), fração vegetativa, variedades

\section{INTRODUCTION}

The demand for corn hybrids with ability for grain production causes breeding companies to turn their attention to the development of increasingly better hybrids for this purpose, generating a shortage of hybrids with specific qualities for silage production (Horst et al., 2020a). Due to the constant increase in demand for silage hybrids and also the requirement for higher quality materials, they make more information about those existing indispensables. That is why comparative research

*Corresponding author: egonhh@yahoo.com.br

Submitted: April 1, 2021. Accepted: May 24, 2021. 
between hybrids is fundamental for the advancement of genetic improvement programs and is essential for technical recommendations given mainly to farmers (Horst et al., 2020b). This type of study may encourage breeding companies to do more to find genetically superior materials than are available.

Among the characteristics of importance for a silage hybrid, these stand out: high participation of grains in the plant, high dry matter and fibrous portion digestibility (Horst et al., 2020b). Daniel et al. (2019) corroborates stating that the quality of the fibrous portion and the starch content are the main limitations for the corn silage quality, and these characteristics may suffer interference from the environment (Krämer-Schmid et al., 2016). The technological standard adopted by farmers and environmental conditions are extremely variable, undergoing intense changes within the same region, or from one crop season to another, influencing the productive and qualitative hybrids behavior (Ferraretto and Shaver, 2015; Tres et al., 2014).

Some factors, such as soil type and fertility, water availability, luminosity, fertilization, density and management, are particular to each farm, varying within the same region, favoring different productive results from the same hybrid, for example (Tres et al., 2014). Therefore, it's fundamental to find hybrids adapted to the soil and climatic conditions to the location where it will be grown (Paziani et al., 2009). Thus, our objective was to evaluate the yield, morphometric and chemical characteristics, and the digestibility of various corn hybrids grown in different locations for silage production.

\section{MATERIAL AND METHODS}

The experiment was carried out in Guarapuava, Paraná, Brazil. The climate of the region is $\mathrm{Cfb}$ (subtropical humid mesothermal), with no dry season, with cool summers and moderate winter according to the Köppen classification, average annual rainfall of $1,944 \mathrm{~mm}$, minimum and maximus average annual temperature of 12.7 and $23.5^{\circ} \mathrm{C}$, respectively and relative humidity of $77.9 \%$.

Four corn hybrids (Zea mays L.) were used: P2866H, P3456H, P30R50VYH and P4285YHR (Pioneer ${ }^{\circledR}$ ), in four locations, defined as A; B; C and D. Farm A is located at latitude $25^{\circ} 31^{\prime} 932^{\prime \prime}$ $\mathrm{S}$, longitude $51^{\circ} 33^{\prime} 437^{\prime \prime} \mathrm{W}$ and at an altitude of $1,080 \mathrm{~m}$. Farm B is located at latitude $25^{\circ} 13^{\prime} 219^{\prime \prime}$ $\mathrm{S}$, longitude $52^{\circ} 22^{\prime} 066^{\prime \prime} \mathrm{W}$ and at an altitude of $1,184 \mathrm{~m}$. Farm C is located at latitude $25^{\circ} 07^{\prime} 705^{\prime \prime}$ $\mathrm{S}$, longitude $51^{\circ} 41^{\prime} 983^{\prime \prime} \mathrm{W}$ and with $1,079 \mathrm{~m}$. Farm D is located at latitude $25^{\circ} 34^{\prime} 075^{\prime \prime} \mathrm{S}$, longitude $51^{\circ} 38^{\prime} 380^{\prime \prime} \mathrm{W}$ and with 1,207 $\mathrm{m}$. Thus, the experiment was conducted in a randomized block design, in a $4 \times 4$ factorial scheme, and three repetitions each (blocks).

The sowing was in no-tillage system in succession with a forage mixture of black oats (Avena strigosa) and ryegrass (Lolium multiflorum). The experiment was implemented in plots of 15 lines with 25 linear meters each, and for each of the evaluations, the useful area used was 10 planting lines with 15 linear meters. On farm A, sowing took place on October 14, 2017, with $0.8 \mathrm{~m}$ line spacing, basic fertilization with a mixture of MAP fertilizers at a dose of $330 \mathrm{~kg} \mathrm{ha}^{-1}, \mathrm{KCl}$ at a dose of $200 \mathrm{~kg} \mathrm{ha}^{-1}$ and Surfurgan at a dose of $100 \mathrm{~kg}$ $\mathrm{ha}^{-1}$, and urea in coverage at a dose of $605 \mathrm{~kg} \mathrm{ha}^{-}$ ${ }^{1}$. In farm B, sowing took place on October 13 , 2017 , with $0.47 \mathrm{~m}$ line spacing, basic fertilization with $\mathrm{N}-\mathrm{P}_{2} \mathrm{O}_{5}-\mathrm{K}_{2} \mathrm{O}$ fertilizer (08-30-20) at a dose of $400 \mathrm{~kg} \mathrm{ha}^{-1}$, and urea in coverage at a dose of 400 $\mathrm{kg} \mathrm{ha}^{-1}$. On farm C, sowing took place on October 19, 2017, with $0.45 \mathrm{~m}$ line spacing, basic fertilization with $\mathrm{N}-\mathrm{P}_{2} \mathrm{O}_{5}-\mathrm{K}_{2} \mathrm{O}$ fertilizer (09-2424) at a dose of $350 \mathrm{~kg} \mathrm{ha}^{-1}$, and urea in coverage at a dose of $400 \mathrm{~kg} \mathrm{ha}^{-1}$. On farm D, sowing took place on October 13, 2017, with $0.80 \mathrm{~m}$ line spacing, basic fertilization with fertilizer $\mathrm{N}-\mathrm{P}_{2} \mathrm{O}_{5}-$ $\mathrm{K}_{2} \mathrm{O}(09-24-24)$ at a dose of $400 \mathrm{~kg} \mathrm{ha}^{-1}$, and urea in coverage at a dose of $400 \mathrm{~kg} \mathrm{ha}^{-1}$.

When the plants reached the hard-grain stage (R5), they were harvested at $20 \mathrm{~cm}$ from the ground. All plants contained in the useful area of each plot were weighed to determine the production of fresh and dry biomass $\left(\mathrm{kg} \mathrm{ha}^{-1}\right)$. Plant heights and ear insertion were measured, and the number of green and yellow leaves per plant was counted. From the plants harvested in the useful area of each plot, a sub-sample of 20 homogeneous plants were immediately sent to the laboratory, where the centesimal composition of plant anatomical structures was determined by manual segmentation of components: stem, green leaves, yellow leaves, husk and corn cob, grains, as well as the dry matter contents of the wholeplant, vegetative fraction and its components. 
Corresponds to the vegetative fraction, the plant without grains, which were removed manually and carefully during anatomical segmentation.

The samples of whole-plant, vegetative fraction and structural components were weighed and predried in a forced air oven at $55^{\circ} \mathrm{C}$ until constant weight was obtained. After drying, these were weighed again to determine the dry matter content (Silva and Queiroz, 2009). Only the whole-plants and vegetative fraction were sequentially ground in a Willey mill, with a $1 \mathrm{~mm}$ mesh sieve.

In the pre-dried samples, the total dry matter (DM) was determined in an oven at $105^{\circ} \mathrm{C}$, crude protein (CP) by micro Kjeldahl method and ash by incineration at $550{ }^{\circ} \mathrm{C}$ for 4 hours, according to AOAC (Official..., 1995). The neutral detergent fiber content (aNDF) was also determined using thermostable $\alpha$-amylase (Termamyl 120L), and lignin, according to Van Soest et al. (1991), and the content of acid detergent fiber (ADF) according to Goering and Van Soest (1970). Hemicellulose (HEM) contents were obtained by difference between NDF and ADF, as well as cellulose (CEL) contents were obtained from the difference between ADF and lignin. The contents of total digestible nutrients (TDN) were obtained by an equation suggested by Bolsen (1996). The content of non-fibrous carbohydrates (NFC) was obtained by the equation: $N F C=100-$ $(a N D F+C P+a s h+E E)$, and the ether extract (EE) content was standardized at $3 \%$, according to NRC (Nutrient..., 2001).

The dry matter digestibility (DMD) in 24 and 48 hours was estimated by the in-situ technique using nylon bags measuring $12 \times 8 \mathrm{~cm}$ and with pores of 40 to $60 \mu \mathrm{m}$, containing $5 \mathrm{~g}$ of sample ground to $1 \mathrm{~mm}$, for later incubation in the rumen (Nocek, 1988). Before incubation, the bags were immersed in water and inserted into the rumen at different times to be retrieve as a group. After removal, the bags were rinsed under running water under moderate handling until the water appeared to be clean. A blank bag was inserted at each time for correction. For this purpose, two steers of 36 months-old, average live weight of
$650 \mathrm{~kg}$, with permanent ruminal fistula were used, previously fed with corn silage ad libitum.

The data were submitted to Shapiro-Wilk and Bartlett tests, in order to verify the assumptions of normality and homogeneity of variance, respectively. Once these assumptions were met, the $\mathrm{F}$ test was applied at 5\% probability through variance analysis (ANOVA; Supplement 1) and then the Tukey test to compare means at $5 \%$ significance through the SAS program (1993).

\section{RESULTS AND DISCUSSION}

Although there was no statistical difference for phenological cycle, in days, until the harvesting moment in R5 stage, it's important to highlight that there was a numerical difference of 23 days between the average of hybrids $\mathrm{P} 2866 \mathrm{H}$ and P4285YHR (149 and 172 days, respectively). The latter showed a difference of three days among locations of the earlier and later harvest, while the others were 11 days of difference (Table 1). Knowing the cycle of each hybrid is essential to outline strategies better adapted to the systems of each farm, enabling the determination of the best time for sowing and harvesting, and foreseeing the realization of crop treatments and possible climatic risks ((Baum et al., 2019; Hetta et al., 2012). These differences on cycles of the same hybrid are already documented when grown in different locations (Pinto et al., 2010).

The hybrid P4285YHR presented the highest plant and ear insertion heights in relation to the others $(2.72 \mathrm{~m}, 1.52 \mathrm{~m}$ respectively), with a minimum height recorded among locations of $2.63 \mathrm{~m}$ and $1.42 \mathrm{~m}$, for height plant and ear insertion. These minimum values are higher than the average of other hybrids tested. In all locations, the four hybrids had sufficient height necessary to be classified as medium size, between 2.20 and $2.80 \mathrm{~m}$ (Pinto et al., 2010). Pinto et al. (2010) also stated that shorter cycle hybrids tend to obtain shorter plant heights, but our data went against what was reported by the authors. We believe that the cycle until flowering has more interference on this variable than the complete physiological cycle. 
Supplement 1. Summary of variance analysis (ANOVA)

\begin{tabular}{|c|c|c|c|c|c|c|c|c|}
\hline & \multicolumn{5}{|c|}{ Mean square } & \multicolumn{3}{|c|}{ Probability } \\
\hline & Hybrid $(\mathrm{H})$ & Location $(\mathrm{L})$ & Block & $\mathrm{H} \times \mathrm{L}$ & Error & Hybrid & Block & $\mathrm{H} \times \mathrm{L}$ \\
\hline Degrees of freedom & 3 & 3 & 2 & 8 & 16 & - & - & - \\
\hline Cycle & 0.1 & 2.81 & 0.1 & 0.5 & 0.4 & 0.432 & 0.332 & 0.225 \\
\hline Plant height & 0.1 & 0.1 & 0.1 & 0.1 & 0.1 & $<0.001$ & $<0.001$ & $<0.001$ \\
\hline Ear height & 0.1 & 0.1 & 0.1 & 0.1 & 0.1 & $<0.001$ & $<0.001$ & $<0.001$ \\
\hline Number of yellow leaves & 4.0 & 6.9 & 0.8 & 5.8 & 0.3 & $<0.001$ & $<0.001$ & $<0.001$ \\
\hline Fresh biomass & $14879^{2}$ & $15676^{2}$ & $8248^{2}$ & $9689^{2}$ & $5036^{2}$ & $<0.001$ & $<0.001$ & 0.004 \\
\hline Dry biomass & $4137^{2}$ & $3497^{2}$ & $2988^{2}$ & $3087^{2}$ & $2587^{2}$ & 0.075 & 0.165 & 0.230 \\
\hline \multicolumn{9}{|l|}{ Dry matter } \\
\hline Plant & 110.6 & 39.6 & 0.1 & 35.9 & 4.8 & $<0.001$ & $<0.001$ & $<0.001$ \\
\hline Vegetative fraction & 40.5 & 23.8 & 30.9 & 5.1 & 3.9 & $<0.001$ & 0.002 & $<0.001$ \\
\hline Stem & 92.8 & 6.9 & 1.4 & 5.0 & 2.5 & $<0.001$ & 0.062 & 0.086 \\
\hline Green leaves & 98.2 & 229.3 & 191.6 & 224.8 & 72.9 & 0.279 & $<0.001$ & 0.001 \\
\hline Yellow leaves & 17.4 & 28.6 & 0.6 & 43.3 & 4.2 & 0.001 & 0.001 & $<0.001$ \\
\hline Husk and corn cob & 60.7 & 129.5 & 1.8 & 23.0 & 5.7 & $<0.001$ & $<0.001$ & 0.002 \\
\hline Grain & 35.7 & 71.8 & 10.5 & 41.1 & 11.8 & 0.045 & 0.002 & 0.006 \\
\hline \multicolumn{9}{|l|}{ Centesimal composition } \\
\hline Stem & 83.9 & 56.0 & 4.1 & 5.8 & 4.7 & $<0.001$ & $<0.001$ & 0.318 \\
\hline Green leaves & 67.5 & 28.1 & 0.4 & 24.5 & 3.5 & $<0.001$ & $<0.001$ & $<0.001$ \\
\hline Yellow leaves & 6.1 & 32.3 & 4.3 & 15.9 & 2.4 & 0.080 & $<0.001$ & $<0.001$ \\
\hline Husk and corn cob & 47.4 & 5.9 & 0.1 & 6.0 & 2.0 & $<0.001$ & 0.051 & 0.015 \\
\hline Grain & 468.9 & 60.3 & 13.4 & 28.5 & 15.2 & $<0.001$ & 0.018 & 0.106 \\
\hline Ash & 1.5 & 0.7 & 0.1 & 0.4 & 0.1 & $<0.001$ & 0.019 & 0.042 \\
\hline Crude protein & 0.3 & 3.5 & 0.2 & 0.4 & 0.3 & 0.398 & $<0.001$ & 0.295 \\
\hline aNDF & 346.9 & 71.3 & 0.5 & 17.8 & 10.0 & $<0.001$ & $<0.001$ & 0.124 \\
\hline Hemicellulose & 140.9 & 51.0 & 7.2 & 16.9 & 9.38 & $<0.001$ & $<0.001$ & 0.118 \\
\hline $\mathrm{ADF}$ & 47.0 & 9.8 & 4.24 & 8.7 & 12.5 & 0.022 & 0.511 & 0.687 \\
\hline Cellulose & 21.6 & 12.2 & 3.99 & 9.0 & 9.9 & 0.112 & 0.314 & 0.516 \\
\hline Lignin & 5.0 & 3.0 & 0.1 & 0.7 & 0.9 & 0.005 & 0.041 & 0.635 \\
\hline NFC & 356.7 & 43.9 & 0.5 & 22.8 & 12.0 & $<0.001$ & 0.024 & 0.100 \\
\hline TDN & 23.0 & 4.8 & 2.0 & 4.3 & 6.1 & 0.020 & 0.511 & 0.686 \\
\hline \multicolumn{9}{|l|}{ ISDMD-24h } \\
\hline Whole plant & 41.5 & 3.2 & 111.2 & 15.4 & 13.2 & 0.040 & 0.865 & 0.353 \\
\hline Vegetative fraction & 26.4 & 16.3 & 197.2 & 14.6 & 5.2 & 0.006 & 0.043 & 0.081 \\
\hline \multicolumn{9}{|l|}{ ISDMD-48h } \\
\hline Whole plant & 197.2 & 31.7 & 30.7 & 15.1 & 18.6 & $<0.001$ & 0.189 & 0.597 \\
\hline Vegetative fraction & 7.4 & 82.0 & 149.3 & 5.6 & 11.3 & 0.586 & 0.001 & 0.845 \\
\hline
\end{tabular}

Table 1. Cycle, morphometric characteristics and biomass yield of four corn hybrids grown for silage in different locations. Average, minimum and maximum values obtained among locations

\begin{tabular}{lcccc}
\hline $\begin{array}{l}\text { Average } \\
\text { (Min - Max) }\end{array}$ & P2866H & P3456H & P30R50VYH & P4285YHR \\
\hline Cycle, days & 149 & 153 & 154 & 172 \\
& $(146-157)$ & $(146-157)$ & $(146-157)$ & $(171-174)$ \\
\cline { 2 - 5 } Plant height, m & $2.57 \mathrm{~b}$ & $2.48 \mathrm{c}$ & $2.51 \mathrm{c}$ & $2.72 \mathrm{a}$ \\
& $(2.48-1.61)$ & $(2.37-2.58)$ & $(2.39-2.68)$ & $(2.63-2.87)$ \\
\cline { 2 - 5 } Ear height, m & $1.31 \mathrm{c}$ & $1.31 \mathrm{c}$ & $1.42 \mathrm{~b}$ & $1.52 \mathrm{a}$ \\
& $(1.18-1.41)$ & $(1.19-1.42)$ & $(1.19-1.61)$ & $(1.42-1.68)$ \\
\cline { 2 - 5 } Number of yellow leaves & $4.3 \mathrm{a}$ & $3.4 \mathrm{~b}$ & $3.0 \mathrm{~b}$ & $3.3 \mathrm{~b}$ \\
& $(3.0-6.7)$ & $(3.0-4.3)$ & $(2.0-4.7)$ & $(2.0-5.3)$ \\
\cline { 2 - 5 } Fresh biomass, kg ha ${ }^{-1}$ & $68,023 \mathrm{~b}$ & $68,880 \mathrm{~b}$ & $70,526 \mathrm{~b}$ & $78,089 \mathrm{a}$ \\
& $(59,589-80,620)$ & $(61,826-73,894)$ & $(63,934-78,708)$ & $(71,688-80,978)$ \\
\cline { 2 - 5 } Dry biomass, kg ha ${ }^{-1}$ & 27,586 & 26,362 & 24,710 & 26,539 \\
& $(25,038-29,205)$ & $(24,733-28,572)$ & $(22,450-26,973)$ & $(24,973-28,722)$ \\
\hline a-c Different letters differ by
\end{tabular}

$\overline{\mathrm{a}-\mathrm{c}}$ Different letters differ by Tukey test at $5 \%$. 
The hybrid P4285YHR has a higher fresh biomass yield $\left(78,089 \mathrm{~kg} \mathrm{ha}^{-1}\right)$ compared to the others, which did not differ between them $(68,023$; 68,880 ; and $70,526 \mathrm{~kg} \mathrm{ha}^{-1}$ for the hybrids P2866H, P3456H, P30R50VYH, respectively). Despite presenting an average of $68 \mathrm{t}$ of fresh biomass per hectare, the hybrid $\mathrm{P} 2866 \mathrm{H}$ had a yield of $59 \mathrm{t}$ in one location and $80 \mathrm{t}$ in another, and this variability is considered unfavorable, precisely due to the difficulty of predictability. Rosa et al. (2004) found that higher hybrids with higher ear insertion had higher potential for fresh biomass yield. It's salutary to say that while higher hybrids tend to have higher biomass yield, smaller hybrids have a higher proportion between grains and vegetative fraction, favoring the quality of silage (Horst et al., 2020a). In addition, smaller plants have better support, reducing stem breakage under conditions of denser populations.

Oliveira et al. (2003) evaluated 22 hybrids in six cultivation locations, and obtained differences in dry biomass yield, reporting an interaction between genotype and environment that provides discrepancies in results of the same hybrid among locations. This behavior was not noticed in the present study, neither for hybrids nor for locations $(\mathrm{P}>0.05)$.

The hybrid $\mathrm{P} 2866 \mathrm{H}$ had the highest number of yellow leaves compared to hybrids $\mathrm{P} 3456 \mathrm{H}$, P30R50VYH and P4285YHR (4.3, 3.4, 3.0, and 3.3 , respectively), again having the greatest variation between minimum and maximum values among them. The smaller number of yellow leaves found in the hybrids $\mathrm{P} 3456 \mathrm{H}, \mathrm{P} 30 \mathrm{R} 50 \mathrm{H}$ and $\mathrm{P} 4285 \mathrm{YHR}$ can be considered an indication of good stay-green (Neumann et al., 2018), which can result in a larger harvest window due to greater hydration during the reproductive phase and/or grain fill. The early yellowing of leaves can also be linked to leaf diseases and considering that there are more resistant hybrids than others in the natural control of these diseases (Malinovsky et al., 2014), it's possible that the hybrid $\mathrm{P} 2866 \mathrm{H}$ is less tolerant to them than others evaluated. This difference can be better observed in one of these locations where there was only one application of fungicide (6.7 yellow leaves for this hybrid).

The hybrid $\mathrm{P} 2866 \mathrm{H}$ presented the highest dry matter content of plant at harvest time in hard grain stage, with $40.95 \%$ (Table 2), followed by the hybrid $\mathrm{P} 3456 \mathrm{H}$ with $38.38 \%$, and then by the hybrids P30R50VYH and P4285YHR with the lowest dry matter content of plant (35.06 and $34.12 \%$, respectively). Again, it's possible to observe the high variation among locations for the hybrid $\mathrm{P} 2866 \mathrm{H}$ (10.53 percentage points). On the other hand, the hybrid P30R50VYH showed variation of only 1.91 percentage points among locations where the most moisture and the least moisture was harvested (34.20 and $36.11 \%$ DM). This stability demonstrated by this hybrid is considered positive because it allows greater predictability of the chosen harvest time. In one of these locations, the hybrid $\mathrm{P} 2866 \mathrm{H}$ was harvested with $46.08 \% \mathrm{DM}$, which raised the hybrid average to $40.95 \%$, which according to criteria proposed by Arriola et al. (2012), exceeds what is considered ideal to obtain adequate fermentation of silage $(30-40 \%)$. This result was already expected, given that shorter cycle hybrids advance their reproductive stages with water loss more rapidly (Horst et al., 2020a).

Like the whole-plant, the lowest DM contents of vegetative fraction, stem, green and yellow leaves, husk and corn cob were observed in hybrid P30R50VYH $\quad(24.70 \%$; $16.86 \%$; $26.04 \%$; $57.75 \%$; and $36.52 \%$, respectively). On the other hand, even though there was no significant difference $(\mathrm{P}>0.05)$ for dry matter of grain, this same hybrid obtained the highest values, with an average of $67.23 \%$ and a maximum value of $71.71 \%$. In farm B, we observed the lowest levels of DM in whole-plant for all hybrids, and we believe that this may be related to the use of Pyraclostrobin based fungicide in this area. According to Haerr et al. (2016), this class of fungicide has stood out for its greening effect, reducing lignification and promoting increased levels of leaf chlorophyll.

High stalk participation in centesimal composition of plant may reduce the ruminal utilization of corn silage due to the characteristics of structural carbohydrate composition of this fraction (Hetta et al., 2012). The hybrid P4285YHR was the one with the highest participation of this component $(\mathrm{P}<0.05)$. The leaves are the component of the vegetative fraction with the greatest digestibility due to the higher concentration of sugars and digestible fiber (Horst et al., 2020b), and the hybrid P4285YHR was the one that had the greatest participation of this component in its centesimal composition. This result explains the high biomass yield of this 
hybrid seen previously. There was no difference for yellow leaves among hybrids, but in one of locations (farm D), the hybrids P2866H, P3456H and P30R50VYH had the maximum values of yellow leaves and minimum of green leaves in the centesimal composition of plant. In that area there was only one application of fungicide. The presence of leaf diseases generates competition for nutrients between fungi and plant itself, causing it to activate some defense mechanisms to try to control the development of the fungus, such as lignification and leaf fall (Haerr et al., 2016), and this can reduce the dry matter and fiber digestibility of plant (Weinberg and Chen, 2013; Der Bedrosian et al., 2012).

Table 2. Dry matter content of plant fractions and centesimal composition of four corn hybrids grown for silage in different locations. Average, minimum and maximum values obtained among locations

\begin{tabular}{|c|c|c|c|c|}
\hline $\begin{array}{l}\text { Average } \\
\text { (Min - Max) }\end{array}$ & P2866H & P3456H & P30R50VYH & P4285YHR \\
\hline \multicolumn{5}{|l|}{ Dry matter, \% AF } \\
\hline Plant & $\begin{array}{c}40.95 \mathrm{a} \\
(35.55-46.08) \\
\end{array}$ & $\begin{array}{c}38.38 b \\
(34.74-40.33) \\
\end{array}$ & $\begin{array}{c}35.06 \mathrm{c} \\
(34.20-36.11) \\
\end{array}$ & $\begin{array}{c}34.12 \mathrm{c} \\
(31.12-39.99) \\
\end{array}$ \\
\hline Vegetative fraction & $\begin{array}{c}28.25 \mathrm{ab} \\
(25.25-32.86) \\
\end{array}$ & $\begin{array}{c}29.93 \mathrm{a} \\
(24.70-32.78) \\
\end{array}$ & $\begin{array}{c}24.70 \mathrm{c} \\
(21.36-28.06) \\
\end{array}$ & $\begin{array}{c}26.88 \mathrm{~b} \\
(24.91-29.04) \\
\end{array}$ \\
\hline Stem & $\begin{array}{c}22.70 \mathrm{a} \\
(21.27-25.24) \\
\end{array}$ & $\begin{array}{c}19.78 b \\
(18.62-20.53) \\
\end{array}$ & $\begin{array}{c}16.86 \mathrm{c} \\
(16.63-17.43) \\
\end{array}$ & $\begin{array}{c}22.60 \mathrm{a} \\
(20.07-23.77) \\
\end{array}$ \\
\hline Green leaves & $\begin{array}{c}28.15 b \\
(25.62-31.96) \\
\end{array}$ & $\begin{array}{c}30.73 \mathrm{a} \\
(29.52-32.80) \\
\end{array}$ & $\begin{array}{c}26.04 b \\
(22.73-30.35) \\
\end{array}$ & $\begin{array}{c}28.22 \mathrm{~b} \\
(22.51-35.08) \\
\end{array}$ \\
\hline Yellow leaves & $\begin{array}{c}55.77 \mathrm{~b} \\
(36.56-77.60) \\
\end{array}$ & $\begin{array}{c}64.31 \mathrm{a} \\
(58.14-69.04) \\
\end{array}$ & $\begin{array}{c}57.75 b \\
(28.38-72.46) \\
\end{array}$ & $\begin{array}{c}62.29 \mathrm{a} \\
(41.52-76.94) \\
\end{array}$ \\
\hline Husk and corn cob & $\begin{array}{c}41.86 \mathrm{a} \\
(35.95-50.29) \\
\end{array}$ & $\begin{array}{c}40.47 \mathrm{ab} \\
(39.70-41.11) \\
\end{array}$ & $\begin{array}{c}36.52 \mathrm{c} \\
(30.78-40.72) \\
\end{array}$ & $\begin{array}{c}38.02 \mathrm{~b} \\
(34.71-41.46) \\
\end{array}$ \\
\hline Grain & $\begin{array}{c}63.49 \\
(55.30-69.81) \\
\end{array}$ & $\begin{array}{c}66.73 \\
(63.31-68.63) \\
\end{array}$ & $\begin{array}{c}67.23 \\
(63.07-71.71) \\
\end{array}$ & $\begin{array}{c}63.82 \\
(61.10-65.90) \\
\end{array}$ \\
\hline \multicolumn{5}{|c|}{ Centesimal composition, \% whole-plant } \\
\hline Stem & $\begin{array}{c}17.88 \mathrm{~b} \\
(14.30-19.50)\end{array}$ & $\begin{array}{c}15.60 \mathrm{~b} \\
(13.50-18.40) \\
\end{array}$ & $\begin{array}{c}17.17 \mathrm{~b} \\
(15.80-18.70)\end{array}$ & $\begin{array}{c}22.20 \mathrm{a} \\
(20.50-24.90) \\
\end{array}$ \\
\hline Green leaves & $\begin{array}{c}11.51 \mathrm{~b} \\
(7.10-15.80) \\
\end{array}$ & $\begin{array}{c}12.07 \mathrm{~b} \\
(10.80-13.60) \\
\end{array}$ & $\begin{array}{c}11.93 \mathrm{~b} \\
(9.00-13.80) \\
\end{array}$ & $\begin{array}{c}16.71 \mathrm{a} \\
(11.70-19.70) \\
\end{array}$ \\
\hline Yellow leaves & $\begin{array}{c}4.51 \\
(1.80-9.10) \\
\end{array}$ & $\begin{array}{c}4.36 \\
(2.60-7.10) \\
\end{array}$ & $\begin{array}{c}3.00 \\
(1.20-6.60) \\
\end{array}$ & $\begin{array}{c}3.09 \\
(1.10-5.90) \\
\end{array}$ \\
\hline Husk and corn cob & $\begin{array}{c}12.23 \mathrm{c} \\
(9.70-14.10)\end{array}$ & $\begin{array}{c}13.33 \mathrm{bc} \\
(12.80-14.30)\end{array}$ & $\begin{array}{c}14.54 \mathrm{~b} \\
(13.00-16.50)\end{array}$ & $\begin{array}{c}16.92 \mathrm{a} \\
(16.00-17.80)\end{array}$ \\
\hline Grain & $\begin{array}{c}53.87 \mathrm{a} \\
(48.80-58.00) \\
\end{array}$ & $\begin{array}{c}54.64 \mathrm{a} \\
(50.90-59.30) \\
\end{array}$ & $\begin{array}{c}53.36 \mathrm{a} \\
(52.60-53.70) \\
\end{array}$ & $\begin{array}{c}41.08 \mathrm{~b} \\
(37.10-45.70)\end{array}$ \\
\hline
\end{tabular}

${ }_{\mathrm{a}-\mathrm{c}}$ Different letters differ by Tukey test at $5 \%$.

In addition to considering the quality of vegetative fraction as essential to obtain silage with good digestibility, it's also unanimous among many authors that the greater participation of grains in the plant, the better the results regarding caloric density and corn silage digestibility tend to be (Horst et al., 2020a; Ferraretto et al., 2018; Khan et al., 2015). In three of the hybrids evaluated here, we obtained participation of grain in the plant above $50 \%$, and this can be considered satisfactory in comparison to other similar studies (Neumann et al., 2017; Kruse et al., 2008). If we extrapolate these values for grain production corrected by moisture (13\%), we can infer that the hybrids $\mathrm{P} 2866 \mathrm{H}, \mathrm{P} 3456 \mathrm{H}, \mathrm{P} 30 \mathrm{R} 50 \mathrm{VYH}$ and
P4285YHR had a yield of 285; 275; 252; and 208 corn bags per hectare.

The ash content of hybrid P2866H (2.33\%; Table 3 ) was significantly lower $(\mathrm{P}<0.05)$ compared to hybrids P30R50VYH and P4285YHR (3.10 and $3.04 \%$, respectively). The crude protein concentration did not differ among hybrids, varying from $6.33 \%$ in the hybrid P4285YHR to $6.68 \%$ in the hybrids $\mathrm{P} 2866 \mathrm{H}$ and P30R50VYH, values close to those described by Horst et al. (2020b) for three other distinct hybrids grown in locations close to the present study. Also without noticing any difference, these authors demonstrated that there is a higher concentration 
of $\mathrm{CP}$ in the leaves compared to other fractions and, therefore, without major differences between hybrids in the participation of this component, hardly any difference in the crude protein will be observed.

Table 3. Nutritional value of four corn hybrids grown for silage and harvested in hard-grain stage, in different locations

\begin{tabular}{lccccc}
\hline Parameter, \% of MS & P2866H & P3456H & P30R50VYH & P4285YHR & S.E.M. \\
\hline Ash & $2.33 \mathrm{~b}$ & $2.67 \mathrm{ab}$ & $3.10 \mathrm{a}$ & $3.04 \mathrm{a}$ & 0.32 \\
Crude protein & 6.68 & 6.53 & 6.68 & 6.33 & 0.37 \\
aNDF & $56.46 \mathrm{~b}$ & $52.88 \mathrm{~b}$ & $57.70 \mathrm{~b}$ & $66.15 \mathrm{a}$ & 0.88 \\
Hemicellulose & $28.04 \mathrm{~b}$ & $25.61 \mathrm{~b}$ & $28.95 \mathrm{~b}$ & $33.88 \mathrm{a}$ & 0.87 \\
ADF & $28.43 \mathrm{~b}$ & $27.27 \mathrm{~b}$ & $28.75 \mathrm{~b}$ & $32.27 \mathrm{a}$ & 0.93 \\
Cellulose & $23.18 \mathrm{~b}$ & $22.27 \mathrm{~b}$ & $23.54 \mathrm{~b}$ & $25.76 \mathrm{a}$ & 0.88 \\
Lignin & $5.24 \mathrm{~b}$ & $5.01 \mathrm{~b}$ & $5.21 \mathrm{~b}$ & $6.51 \mathrm{a}$ & 0.49 \\
NFC & $31.53 \mathrm{ab}$ & $34.92 \mathrm{a}$ & $29.52 \mathrm{~b}$ & $24.49 \mathrm{c}$ & 0.93 \\
TDN & $67.94 \mathrm{ab}$ & $68.74 \mathrm{a}$ & $67.71 \mathrm{ab}$ & $65.25 \mathrm{~b}$ & 0.78 \\
ISDMD-24h & & & & & \\
Whole plant & $37.03 \mathrm{a}$ & $38.10 \mathrm{a}$ & $36.11 \mathrm{ab}$ & $34.00 \mathrm{~b}$ & 0.95 \\
Vegetative fraction & $26.61 \mathrm{~b}$ & $29.37 \mathrm{a}$ & $25.69 \mathrm{~b}$ & $28.28 \mathrm{a}$ & 1.03 \\
ISDMD-48h & & & & & \\
Whole plant & $55.13 \mathrm{~b}$ & $57.98 \mathrm{a}$ & $55.28 \mathrm{~b}$ & $47.84 \mathrm{c}$ & 0.75 \\
Vegetative fraction & 39.65 & 39.46 & 39.06 & 38.54 & 0.91 \\
\hline
\end{tabular}

${ }^{\mathrm{a}-\mathrm{c}}$ Different letters differ by Tukey test at $5 \%$.

aNDF: Neutral detergent fiber; ADF: acid detergent fiber; NFC: non-fibrous carbohydrate; TDN: Total digestible nutrient; ISDMD-24h: In situ dry matter digestibility on 24 hours of ruminal incubation; ISDMD-48h: In situ dry matter digestibility on 48 hours of ruminal incubation; S.E.M.: Standard error of mean

The hybrid P4285YHR had the highest $(\mathrm{P}<0.05)$ contents of all components related to the plant cell wall, with an average of $66.15 \% ; 33.88 \%$; $32.27 \%$; $25.76 \%$; and $6.51 \%$ for aNDF, hemicellulose, ADF, cellulose and lignin, respectively. For this reason, this hybrid had the lowest NFC content (24.49\%). The other three hybrids evaluated did not differ for cell wall components, while hybrids $\mathrm{P} 3456 \mathrm{H}$ and $\mathrm{P} 2866 \mathrm{H}$ had higher levels of NFC (34.92 and 31.53\%, respectively). We believe that the higher content of fiber components found in the hybrid P4285YHR is directly related to the higher plant height presented by this hybrid, because the elongation of stem increases its participation, and this fraction has a great influence on fiber concentration in the plant (Horst et al., 2020b) and silage.

The aNDF is composed of cell wall structures, consisting of cellulose, hemicellulose and lignin, and is directly related to the capacity of ingestion by ruminants, as it promotes physical occupation of ruminal space (Neumann et al., 2017). While the ADF intermediates the digestion potential of fibrous fraction (Van Soest, 1994), as it's composed of cellulose, which has intermediate digestibility, and lignin, which is indigestible. Therefore, low levels of aNDF and ADF are preferable when choosing hybrids for silage production. The values of aNDF and ADF in this study are close to those described by Ferraretto and Shaver (2015) and Ferreira et al. (2011).

It's possible that a greater number of yellow leaves on a corn plant leads to a higher lignin content (Hetta et al., 2012). However, we observed that these two variables were unrelated in our study, and that it may be an intrinsic characteristic of each hybrid to deposit more or less lignin in its cell structure according to situations occurring in each environment (water stress, leaf diseases, fertilization level, soil characteristics, e.g.).

In general, dry matter digestibility is reduced due to lignification and increased cell wall thickness (Hetta et al., 2012). Differences in cell wall digestibility of corn plants have already been described experimentally in vitro (Deaville and Givens, 2001) and in vivo (Jensen et al., 2005). The hybrid P4285YHR, which had the highest lignin content, had the lowest whole-plant ISDMD ( $\mathrm{P}<0.05)$, either in 24 or 48 hours (34.00 and $47.84 \%$, respectively). We note, however, that this result was not repeated for vegetative fraction ISDMD, where there is the highest lignin concentration (Horst et al., 2020b), suggesting 
that the lower participation of grains of this hybrid has had greater interference in this result. According to Krämer-Schmid et al. (2016), lignin may have a low correlation with dry matter digestibility, and its three-dimensional arrangement may influence this characteristic more than its own participation in the plant.

The hybrid P3456H had whole-plant ISDMD-24h statistically similar to hybrids $\mathrm{P} 2866 \mathrm{H}$ and P30R50VYH, but had vegetative fraction ISDMD-24h higher than them (29.37\%). As the vegetative fraction has a longer time in the rumen, its real changes in digestibility of the intake are highlighted in longer incubation times, and we confirm this by noting that the hybrid $\mathrm{P} 3456 \mathrm{H}$ had the largest whole-plant ISDMD-48h (57,98 \%; P $<0.05)$.

The calculated TDN values showed a trend very close to that observed in the ISDMD of the wholeplant, with the hybrid $\mathrm{P} 3456 \mathrm{H}$ presenting the highest estimated value $(68.74 \%)$, and the hybrid P4285YHR the lowest among them (65.25\%).

\section{CONCLUSION}

We noticed that lower fibrous carbohydrates and lignin content, higher fibrous carbohydrates content, together with satisfactory grains participation in the plant structure led to a greater dry matter digestibility. Hybrids with lower plant heights do not necessarily have lower dry biomass yields, but hybrids of greater height and with high stem and leaf participation tend to have a higher aFDN content and less dry matter digestibility.

\section{REFERENCES}

ARRIOLA, K.G.; KIM, S.C.; HUISDEN, C.M.; ADESOGAN, A.T. Stay-green ranking and maturity of corn hybrids: 1 . Effects on dry matter yield, nutritional value, fermentation characteristics, and aerobic stability of silage hybrids in Florida. J. Dairy Sci., v.95,p.964-974, 2012.

BAUM, M.E.; ARCHONTOULIS, S.V.; LICHT, M.A. Planting date, hybrid maturity, and weather effects on maize yield and crop stage. Agron. J., v.111, p.303-313, 2019.

BOLSEN, K.K.; ASHBELL, G.; WEINBERG, Z.G. Silage fermentation and silage additives review. J. Anim. Sci., v.9, p.483-494, 1996.
DANIEL, J.L.P.; BERNARDES, T.F.; JOBIM, C.C. et al. Production and utilization of silages in tropical areas with focus on Brazil. Grass Forage Sci., v.74, p.188-200, 2019.

DEAVILLE, E.R.; GIVENS, D.I. Use of the automated gas production technique to determine the fermentation kinetics of carbohydrate fractions in maize silage. Anim. Feed Sci. Technol., v.93, p.205-215, 2001.

DER BEDROSIAN, M.C.; NESTOR JR, K.E.; KUNG JR, L. The effects of hybrid, maturity, and length of storage on the composition and nutritive value of corn silage. J. Dairy Sci., v.95, p.51155126, 2012.

FERRARETTO, L.F.; SHAVER R.D. Effects of whole-plant corn silage hybrid type on intake, digestion, ruminal fermentation, and lactation performance by dairy cows through a metaanalysis. J. Dairy Sci., v.98, p.2662-2675, 2015.

FERRARETTO, L.F.; SHAVER, R.D.; LUCK, B.D. Silage review: Recent advances and future technologies for whole-plant and fractionated corn silage harvesting. J. Dairy Sci., v.101, p.3937-3951, 2018 .

FERREIRA, G.D.G.; BARRIÈRE, Y.; JOBIM, C.C.; ALMEIDA, O.D. Valor nutritivo da silagem de dez híbridos de milho. Acta Sci. Anim. Sci., v.33, p.255-260, 2011.

GOERING, H.K.; VAN SOEST, P.J. Forage fiber analysis. Agricultural handbook no. 379. Washington: US Department of Agriculture, 1970. p.1-20.

HAERR, K.J.; PINEDA, A.; LOPES, N.M.; WEEMS, J.D. et al. Effects of corn treated with foliar fungicide on in situ corn silage degradability in Holstein cows. Anim. Feed Sci. Technol., v.222, p.149-157, 2016.

HETTA, M.; MUSSADIQ, Z.; GUSTAVSSON, A.M.; SWENSSON, C. Effects of hybrid and maturity on performance and nutritive characteristics of forage maize at high latitudes, estimated using the gas production technique. Anim. Feed Sci. Technol., v.171, p.20-30, 2012.

HORST, E.H.; BUMBIERIS JR, V.H.; NEUMANN, M.; SOUZA, A.M. et al. Agronomic characteristics of maize hybrids (Zea mays, L.) at different maturity stages. Semina: Ciênc. Agrár., v.41, Supl.5, p.2273-2284, 2020a. 
HORST, E.H.; LÓPEZ, S.; NEUMANN, M.; GIRÁLDEZ, F.J. et al. Effects of hybrid and grain maturity stage on the ruminal degradation and the nutritive value of maize forage for silage. Agriculture, v.10, p.251-263, $2020 \mathrm{~b}$.

JENSEN, C.; WEISBJERG, M.R.; NØRGAARD, P.; HVELPLUND, T. Effect of maize silage maturity on site of starch and NDF digestion in lactating dairy cows. Anim. Feed Sci. Technol., v.118, p.279-294, 2005.

KHAN, N.A.; YU, P.; ALI, M.; CONE, J.W. et al. Nutritive value of maize silage in relation to dairy cow performance and milk quality. J. Sci. Food Agric., v.95, p.238-252, 2015.

KRÄMER-SCHMID, M.; LUND, P.; WEISBJERG, M.R. Importance of NDF digestibility of whole crop maize silage for dry matter intake and milk production in dairy cows. Anim. Feed Sci. Technol., v.219, p.68-76, 2016.

KRUSE, S.; HERRMANN, A.; KORNHER, A. Evaluation of genotype and environmental variation in fiber content of silage maize using a model-assisted approach. Eur. J. Agro, v.28, p.210-223, 2008.

MALINOVSKY, F.G.; FANGEL, J.U.; WILLATS, W.G. The role of the cell wall in plant immunity. Front. Plant Sci., v.5, p.178-190, 2014.

NEUMANN, M.; GHIZZI, L.; JUNIOR, J.C.H.; CARNEIRO, M.K. et al. Produção de forragem de milho em diferentes densidades de semeadura e épocas de colheita. Rev. Bras. Milho Sorgo, v.16, p.204-216, 2017.

NEUMANN, M.; POCZYNEK, M.; LEÃO, G.F.M.; FIGUEIRA, D.N. et al. Desempenho de híbridos de milho para silagem cultivados em diferentes locais com três densidades populacionais. Rev. Bras. Milho Sorgo, v.17, p.49-62, 2018.

NOCEK, J.E. In situ and other methods to estimate ruminal protein and energy digestibility: a review. J. Dairy Sci., v.71, p.2051-2069, 1988.

OFFICIAL methods of analysis. 16.ed. Washington: AOAC, 1995. 2000p.
OLIVEIRA, J.S.E.; SOBRINHO, F.D.S.; PEREIRA, R.C.; MIRANDA, J.M. et al. Potencial de utilização de híbridos comerciais de milho para silagem, na região sudeste do Brasil. Rev. Bras. Milho Sorgo, v.2, p.62-71, 2003.

PAZIANI, S.F.; DUARTE, A.P.; NUSSIO, L.G.; GALLO, P.B. et al. Características agronômicas e bromatológicas de híbridos de milho para produção de silagem. Rev. Bras. Zoote., v.38, p.411-417, 2009.

PINTO, A.P.; LANÇANOVA, J.A.C.; LUGÃO, S.M.B.; ROQUE, A.P. et al. Avaliação de doze cultivares de milho (Zea mays L.) para silagem. Semin. Ciênc. Agrár., v.31, p.1071-1078, 2010.

ROSA, J.R.P.; SILVA, J.H.S.; RESTLE, J.; PASCOAL, L.L. et al. Avaliação do comportamento agronômico da planta e valor nutritivo da silagem de diferentes híbridos de milho (Zea mays, L.). Rev. Bras. Zootec., v.33, p.302-312, 2004.

SAS INSTITUTE. SAS Language reference. Version 6, Cary, NC: 1042 p. 1993.

SILVA, D.J.; QUEIROZ, A.C. Análise de alimentos (métodos químicos e biológicos). 3.ed. Viçosa: UFV, 22009. 35p.

TRES, T.; JOBIM, C.C.; PINTO, B.R.J.; SOUZA NETO, I.L. et al. Composição nutricional e digestibilidade in vitro de genótipos de milho produzidos em dois anos agrícolas. Semin. Ciênc. Agrár., v.35, p.3249-3261, 2014.

VAN SOEST, P.J. Nutritional ecology of the ruminant. 2.ed. Ithaca: Cornell Univ. Press, 1994.

VAN SOEST, P.J.; ROBERTTSON, J.B.; LEWIS, B.A. Methods for dietary fiber, neutral detergent fiber, and nonstarch polysaccharides in relation to animal nutrition. J. Dairy Sci., v.74, p.3583-3597, 1991.

WEINBERG, Z.G.; CHEN, Y. Effects of storage period on the composition of whole crop wheat and corn silages. Anim. Feed Sci. Technol., v.185, p.196-200, 2013. 